\title{
Time taken for growing pigs to acclimate to change in ambient temperature
}

\author{
J. M. F. Verhagen ${ }^{1 *}$, R. Geers ${ }^{2}$ and M. W. A. Verstegen ${ }^{1}$ \\ ${ }^{1}$ Department of Animal Husbandry, Wageningen Agricultural University, P.O. \\ Box 338, NL 6700 AH Wageningen, Netherlands \\ ${ }^{2}$ Laboratory for agricultural Building Research, Catholic University of Leuven, \\ Kardinaal Mercierlaan 92, 3030 Heverlee, Belgium
}

Received 23 October 1986; accepted 6 May 1987

Key words: pigs, housing, climate, feed intake, energy balance

\begin{abstract}
In 4 almost identical trials, acclimation to 15 and $25^{\circ} \mathrm{C}$ of 2 groups of 10 grouphoused young pigs of liveweight $20 \mathrm{~kg}$, previously identically kept at $20^{\circ} \mathrm{C}$, was assessed over 12 days from the time course of rate of gain, intake of metabolizable energy (ME) and rate of heat production. During the first 6 days, rate of gain was $57 \mathrm{~g} \cdot \mathrm{d}^{-1}$ and ME intake was $166 \mathrm{~kJ} \cdot \mathrm{kg}^{-0.75} \cdot \mathrm{d}^{-1}$ less at $15^{\circ} \mathrm{C}$ than at $25^{\circ} \mathrm{C}$. However the rates then ( $7-12$ days) increased in pigs at $15^{\circ} \mathrm{C}$ by $85 \mathrm{~g} \cdot \mathrm{d}^{-1}$ and 127 $\mathrm{kJ} \cdot \mathrm{kg}^{-0.75} \cdot \mathrm{d}^{-1}$. Pigs acclimated to low temperature more quickly during daylight than during darkness. Acclimation was related to activity of the pigs, assessed ultrasonically, with burglar devices and was established in 8 days at $15^{\circ} \mathrm{C}$ and in 5 days at $25{ }^{\circ} \mathrm{C}$.
\end{abstract}

\section{Introduction}

Commercial pig production can be improved if one knows the climatic requirements to maximize gain and efficiency of utilization of resources (Close, 1981). Climate also influences well-being and health of pigs (Blecha \& Kelly, 1981; Close, 1981). Temperature may influence both the incidence and the severity of diseases (Kelly, 1980; Dantzer \& Mormede, 1983). Not only temperature itself but also change in temperature influence the pig (Siegel, 1980), which adapts to cold in behaviour, physiology and morphology (Mount, 1979). Long-term exposure to cold increases feed intake after an initial delay (Leung \& Horowitz, 1976). Such a delay in adjustment of feed intake to cold takes about 5 days in mice (Barnett $\&$ Mount, 1967).

* Present address: Fomeva BV, P.O. Box 303, 5430 AH Cuyk, Netherlands. 
Adaptation to one climatic factor, called acclimation, depends on feed supply (Mount, 1979). It is expressed physiologically as an increase in metabolic heat production (Mount et al., 1980), when the temperature falls below the thermoneutral zone or critical temperature. Variation in metabolic rate with time of day is influenced by ambient temperature (Close, 1971; van der Hel et al., 1984). Acclimation is expressed behaviorally by more activity and, in group-housed pigs, by huddling together to reduce heat loss (Mount, 1979; van der Hel et al., 1986). Holmes \& Mount (1967) have stressed the importance of assessing effects of ambient temperature in group-housed pigs rather than singly housed pigs to allow such behavioral adaptation. Activity of young growing pigs may account for $10-30 \%$ of heat production (Verstegen et al., 1982; Thorbek et al., 1982). Acclimation is expressed morphologically in pigs long exposed to cold by changes in coat and in subcutaneous fat, which increase thermal insulation (Mount, 1979; Christison \& Williams, 1982).

We assessed how long it took pigs to adjust to a change in temperature of $5^{\circ} \mathrm{C}$ upwards to a thermoneutral temperature of $25^{\circ} \mathrm{C}$ and downwards to $15^{\circ} \mathrm{C}$ below the thermoneutral zone for group-housed pigs (Bruce \& Clark, 1979). We took a stable metabolic rate as a criterion that acclimation was complete.

\section{Materials and methods}

\section{Animals and accommodation}

We used Large White $\times$ Dutch Landrace gilts and castrated males. In each trial, all the pigs were from the same herd and weighed about $20 \mathrm{~kg}$ initially (Table 1). They had been housed in a similar environment after weaning on the farm. Directly after arrival, we weighed each pig and allotted it to pens, each with 10 pigs. There were two pens in each of two respiration chambers. On the basis that hyperactivity of pigs after transfer disappears in two to three days (Dantzer, 1973), we kept them all at $20^{\circ} \mathrm{C}$ for 2 days to allow acclimatization.

The respiration chambers each had a volume capacity of $80 \mathrm{~m}^{3}$ and a floor space

Table 1. Mean $(m)$ and standard error of the mean $(s)$ of liveweight at the start of the trials with two environmental temperatures.

\begin{tabular}{|c|c|c|c|c|}
\hline \multirow{2}{*}{$\begin{array}{l}\text { Temperature } \\
\left({ }^{\circ} \mathrm{C}\right)\end{array}$} & \multirow[t]{2}{*}{ Replicate } & \multirow{2}{*}{$\begin{array}{l}\text { Number of } \\
\text { animals }\end{array}$} & \multicolumn{2}{|c|}{ Liveweight ( $\mathrm{kg}$ ) } \\
\hline & & & $m$ & $s$ \\
\hline \multirow[t]{4}{*}{25} & 1 & 20 & 22.3 & 0.43 \\
\hline & 2 & 20 & 20.4 & 0.55 \\
\hline & 3 & 20 & 21.5 & 0.57 \\
\hline & 4 & 20 & 21.7 & 0.47 \\
\hline \multirow[t]{4}{*}{15} & 1 & 20 & 21.7 & 0.50 \\
\hline & 2 & 20 & 21.5 & 0.42 \\
\hline & 3 & 20 & 22.5 & 0.76 \\
\hline & 4 & 19 & 20.5 & 0.41 \\
\hline
\end{tabular}


of $18 \mathrm{~m}^{2}$. The floor was of atoxic asphalt and a tenth was slatted. Relative humidity was maintained at about 0.65 and air speed at below $0.2 \mathrm{~m} \cdot \mathrm{s}^{-1}$. The chambers were lit from $07 \mathrm{~h} 00$ to $19 \mathrm{~h} 00$.

\section{Feeding}

Since cold and restricted feed intake have an additive effect (Hacker et al., 1973; Fuller \& Boyne, 1972), we offered feed to appetite so that the pigs could adjust their intake. All pigs were offered pellets in self-feeders and had free access to water. The pellets had a mass fraction of crude protein of 0.17 . Those of Trials $1-3$ had a gross energy content of $16.4 \mathrm{MJ} / \mathrm{kg}$ and those of Trial 4 of $17 \mathrm{MJ} / \mathrm{kg}$. During the preliminary period, the pigs later kept at 15 and $25^{\circ} \mathrm{C}$ ate 804 (s.d. 130) and 876 (s.d. 96) $\mathrm{g} \cdot \mathrm{d}^{-1}$, respectively.

\section{Experimental design}

After acclimatization, the randomized groups were kept at ambient temperatures of 15 and $25^{\circ} \mathrm{C}$ for 12 days (Fig. 1). We repeated the trial four times.

\section{Measurements}

Metabolizability of feed was measured for successive periods of 6 days, in order to assess partitioning of energy into energy requirement for maintenance and for accretion of protein and fat, as reported elsewhere (Verhagen et al., 1987).

Intake of metabolizable energy (calculated from gross energy in feed minus energy in faeces, urine and refused feed) was expressed with reference to metabolic body size (metabolizable energy divided by body mass to the power $0.75\left(\mathrm{~m}^{0.75}\right.$ expressed in $\mathrm{kg}^{0.75}$ ) and by time).

The pigs were weighed after 6 and 12 days.

Heat production was calculated by the method of Brouwer (1965) from continuous measurements of exchange of oxygen and carbon dioxide (time interval $18 \mathrm{~min}$ ) by the procedure of Verstegen et al. (1987) over periods of $48 \mathrm{~h}$, taking Days 2-3, 56, 8-9 and 11-12 in each trial (Fig. 1), in other words for 8 of the 12 days.

Activity was assessed from ultrasonic measurements over 6-min periods by the method of Wenk \& van Es (1976) and aggregated results for 18-min periods, as for heat production.

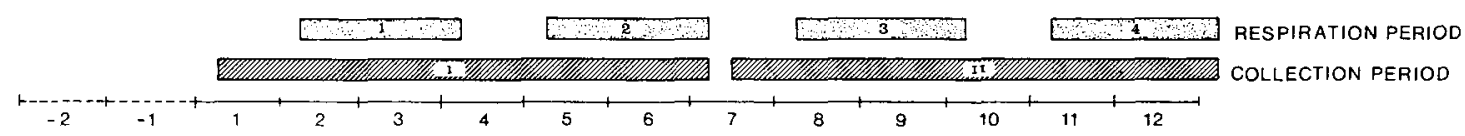

LIMINARY PERIOD

at $20^{\circ} \mathrm{C}$

Fig. 1. Experimental design. 


\section{Statistical analysis}

The data were grouped by time of day and by time during the experimental period. Acclimation was assessed by the following model (SAS, 1985) for heat production $(H)$ as a function of time $(D)$ for ambient temperature $(T)$ :

$$
H_{i j k}=\mu+T_{i}+t_{j}+D_{k}+(T \times D)_{\mathrm{ik}}+e_{i j k}
$$

where $H$ is overall heat production, $\mu$ is the overall mean heat production, $T$ is temperature, $t$ is trial number, $D$ is time, and $e$ is residual error, with the series $i=1,2$, $j$ is $1,2,3,4$ and $k=2,3,5,6,8,9,11,12$.

Acclimation in relation to activity and to metabolism was analysed by Equation 1 for activity-free heat production $\left(H_{\mathrm{F}}\right)$ and activity-related heat production $\left(H_{\mathrm{A}}\right)$. Activity was regressed on heat production separately for each trial, for light and for dark, because pigs are diurnal animals differing in metabolic rate and activity between day and night (Mount, 1979) and because metabolic rate and activity are influenced by ambient temperature (Close, 1971; Mount, 1979; van der Hel et al., 1984). Activity-free heat production was calculated by subtracting activity-related heat production from the total. Means for $H_{\mathrm{F}}$ and $H_{\mathrm{A}}$ were calculated for light and darkness for each day.

The effects of trial and time were also analysed for each treatment separately. The model for activity-related and activity-free heat production in relation to time was as follows:

$$
H_{j k}=\mu+t_{j}+D_{k}+e_{j k}
$$

The model used as a gauge of time of acclimation was as follows:

$$
H_{j k}=\mu+t_{j}+b \cdot k+e_{j k}
$$

where $b$ is a regression coefficient. Within a treatment, a significant regression coefficient indicated a significant change in heat production with time. Coefficients for each treatment were tested by the variance ratio test (Snedecor \& Cochran, 1976) against a pooled coefficient for both treatments, in order to detect differences between treatments in the course of heat production.

\section{Results}

Pigs kept at $15{ }^{\circ} \mathrm{C}$ had a lower intake of metabolizable energy (ME), heat production and rate of gain than pigs kept at $25^{\circ} \mathrm{C}$ (Table 2). Feed conversion was not affected by temperature (Table 2). During the first 6 days, they gained significantly less, $57 \mathrm{~g} \cdot \mathrm{d}^{-1}$, and consumed significantly less $\mathrm{ME}, 166 \mathrm{~kJ} \cdot \mathrm{kg}^{-0.75} \cdot \mathrm{d}^{-1}(P<0.05)$. In the period 7-12 days, they significantly increased their gain by $85 \mathrm{~g} \cdot \mathrm{d}^{-1}$ and their intake of ME by $127 \mathrm{~kJ} \cdot \mathrm{kg}^{-0.75} \cdot \mathrm{d}^{-1}(P<0.05)$ (Fig. 2).

Feed intake (Table 3 ) at 15 and $25^{\circ} \mathrm{C}$ increased from the period 2-3 days to 11-12 
Table 2. Intake of metabolizable energy $\left(\mathrm{kJ} \cdot \mathrm{kg}^{-0.75} \cdot \mathrm{d}^{-1}\right)$, heat production $\left(\mathrm{kJ} \cdot \mathrm{kg}^{-0.75} \cdot \mathrm{d}^{-1}\right)$, gain $\left(\mathrm{g}^{\circ} \mathrm{d}^{-1}\right)$ and feed conversion. $\bar{x}$ : mean. $s$ : standard error of mean.

\begin{tabular}{llllll}
\hline Temperature & Replicate & $\begin{array}{l}\text { Metabolizable } \\
\text { energy }\end{array}$ & $\begin{array}{l}\text { Heat } \\
\text { production }\end{array}$ & $\begin{array}{l}\text { Daily } \\
\text { gain }\end{array}$ & $\begin{array}{l}\text { Feed } \\
\text { conversion }\end{array}$ \\
$25{ }^{\circ} \mathrm{C}$ & 1 & 1417 & 881 & 707 & 1.77 \\
& 2 & 1420 & 878 & 467 & 2.49 \\
& 3 & 1254 & 808 & 522 & 2.24 \\
& 4 & 1773 & 941 & 794 & 1.87 \\
$\bar{x} \pm s$ & & $1462 \pm 109.4$ & $876 \pm 27.2$ & $622 \pm 76.8$ & $2.09 \pm 0.17$ \\
$15{ }^{\circ} \mathrm{C}$ & 1 & 1390 & 879 & 591 & 2.06 \\
& 2 & 1388 & 878 & 553 & 2.23 \\
& 3 & 1196 & 830 & 563 & 2.14 \\
& 4 & 1497 & 864 & 680 & 1.80 \\
$\bar{x} \pm s$ & & & & & \\
\hline
\end{tabular}

days by 313 and $203 \mathrm{~g} \cdot \mathrm{d}^{-1}$, respectively. Heat production at $15^{\circ} \mathrm{C}$ increased for 9 days. It was less than for pigs at $25^{\circ} \mathrm{C}$ for 11 days (Fig. 3). Pigs at $15{ }^{\circ} \mathrm{C}$ required $12 \%$ more energy for maintenance. It took 6 days for them to increase intake of metabolizable energy. After that, their feed intake and energy requirement for maintenance were similar to those of pigs kept at $25^{\circ} \mathrm{C}$.

Heat production was 83 and $114 \mathrm{~kJ} \cdot \mathrm{kg}^{-0.75} \cdot \mathrm{d}^{-1}$ more in the light than in the dark for the respective treatments $(P<0.05)$ (Tables 4 and 5; Fig. 4). The effect of treatment on heat production was significant only for the periods in the light (Tables).

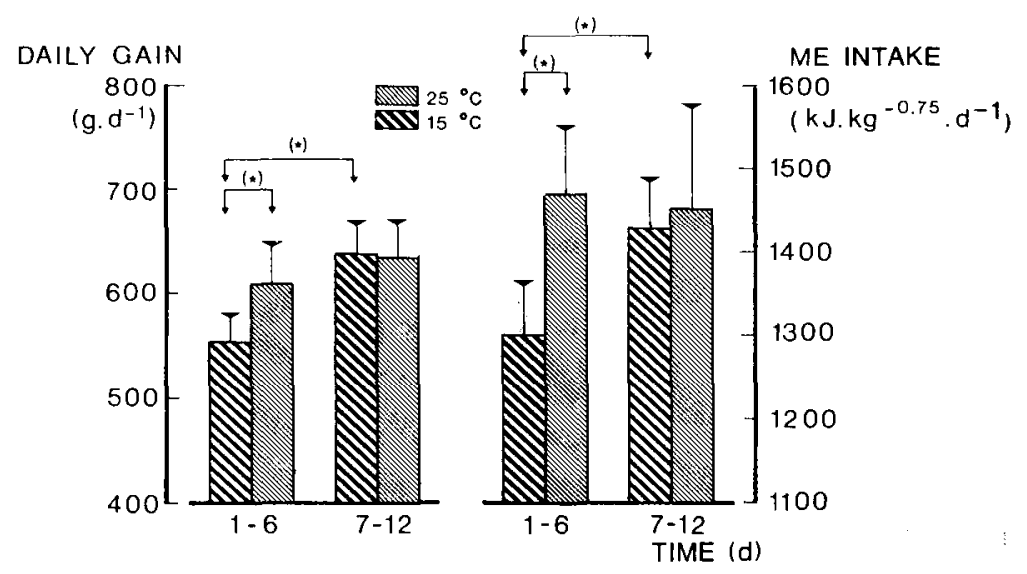

(*) SIGNIFICANT DIFFERENCE $(P<0.05)$

Fig. 2. Daily gain $\left(g \cdot \mathrm{d}^{-1}\right)$ and intake of metabolizable energy (ME) $\left(\mathrm{kJ} \cdot \mathrm{kg}^{-0.75} \cdot \mathrm{d}^{-1}\right)$ for each temperature treatment and for both periods. 


\section{J. M. F. VERHAGEN, R. GEERS AND M. W. A. VERSTEGEN}

Table 3. Feed intake $\left(\mathrm{g} \cdot \mathrm{d}^{-1}\right)$ and energy requirement for maintenance $\left(\mathrm{kJ}^{\circ} \mathrm{kg}^{-0.75} \cdot \mathrm{d}^{-1}\right)$ of pig at various times during keeping at 25 and $15^{\circ} \mathrm{C} . \bar{x}$ : mean; $s$ : standard error of mean.

\begin{tabular}{|c|c|c|c|c|c|c|c|c|}
\hline \multirow{3}{*}{$\begin{array}{l}\text { Time } \\
\text { (d) }\end{array}$} & \multicolumn{4}{|c|}{ Feed intake $\left(\mathrm{g} \cdot \mathrm{d}^{-1}\right)$} & \multicolumn{4}{|c|}{ Energy requirement $\left(\mathrm{kJ} \cdot \mathrm{kg}^{-0.75} \cdot \mathrm{d}^{-1}\right)$} \\
\hline & \multicolumn{2}{|l|}{$25^{\circ} \mathrm{C}$} & \multicolumn{2}{|c|}{$15^{\circ} \mathrm{C}$} & \multicolumn{2}{|c|}{$25^{\circ} \mathrm{C}$} & \multicolumn{2}{|c|}{$15^{\circ} \mathrm{C}$} \\
\hline & $\bar{x}$ & $s$ & $\vec{x}$ & $s$ & $\dot{x}$ & $s$ & $\bar{x}$ & $s$ \\
\hline $2+3$ & 1125 & 29.0 & 1060 & 37.0 & 514 & 24 & 579 & 37 \\
\hline $5+6$ & 1241 & 73.5 & 1144 & 19.5 & 501 & 38 & 553 & 37 \\
\hline $8+9$ & 1305 & 75.0 & 1300 & 11.0 & 559 & 65 & 571 & 25 \\
\hline $11+12$ & 1328 & 99.0 & 1375 & 26.5 & 559 & 36 & 564 & 49 \\
\hline
\end{tabular}

Table 4. Heat production $\left(\mathrm{kJ}^{\mathrm{k}} \mathrm{kg}^{-0.75} \cdot \mathrm{d}^{-1}\right)$ in the dark $(19: 00-07: 00 \mathrm{~h})$ and the light $(07: 00-19: 00 \mathrm{~h}) \cdot \bar{x}$ : mean; $s$ : standard error of mean.

\begin{tabular}{|c|c|c|c|c|c|}
\hline \multirow[t]{3}{*}{ Temperature } & \multirow[t]{3}{*}{ Replicate } & \multicolumn{4}{|c|}{ Heat production } \\
\hline & & \multicolumn{2}{|c|}{ dark } & \multicolumn{2}{|c|}{ light } \\
\hline & & $\bar{x}$ & $s$ & $\bar{x}$ & $s$ \\
\hline \multirow[t]{4}{*}{$25^{\circ} \mathrm{C}$} & 1 & 808 & 11.6 & 960 & 11.8 \\
\hline & 2 & 806 & 8.3 & 920 & 21.8 \\
\hline & 3 & 767 & 8.3 & 856 & 7.4 \\
\hline & 4 & 894 & 19.5 & 997 & 15.2 \\
\hline $\bar{x}$ & & 819 & 11.9 & 933 & 14.1 \\
\hline \multirow[t]{4}{*}{$15^{\circ} \mathrm{C}$} & 1 & 850 & 8.6 & 913 & 14.9 \\
\hline & 2 & 831 & 7.3 & 931 & 15.6 \\
\hline & 3 & 796 & 10.0 & 867 & 15.6 \\
\hline & 4 & 820 & 12.1 & 917 & 16.3 \\
\hline $\bar{x}$ & & 823 & 9.5 & 906 & 15.6 \\
\hline
\end{tabular}

Table 5. Significance of the effects of temperature, replicate and time on heat production $(H)$, activityassociated heat production $\left(H_{\mathrm{A}}\right)$ and activity-free heat production $\left(H_{\mathrm{F}}\right) \cdot r^{2}=$ coefficient of determination: fraction of variance explained by the statistical model (Model 1 ).

\begin{tabular}{|c|c|c|c|c|c|c|}
\hline & \multicolumn{3}{|c|}{ Light } & \multicolumn{3}{|c|}{ Dark } \\
\hline & $H$ & $H_{\mathrm{A}}$ & $H_{\mathrm{F}}$ & $H$ & $H_{\mathrm{A}}$ & $H_{\mathrm{F}}$ \\
\hline Temperature & ** & n.s. & $* *$ & n.s. & $* *$ & n.s. \\
\hline Replicate within temperature & *** & $* *$ & $* *$ & $* *$ & ** & $* *$ \\
\hline Time & $* *$ & ** & ** & n.s. & ** & ** \\
\hline $\begin{array}{l}\text { Temperature } \times \text { time interaction } \\
r^{2}(\%)\end{array}$ & $\begin{array}{l}\text { n.s. } \\
85.2\end{array}$ & $\begin{array}{l}\text { n.s. } \\
89.9\end{array}$ & $\begin{array}{l}\text { n.s. } \\
83.9\end{array}$ & $\begin{array}{l}\text { n.s. } \\
73.7\end{array}$ & $\begin{array}{l}\text { n.s. } \\
88.6\end{array}$ & $\begin{array}{l}\text { n.s. } \\
71.2\end{array}$ \\
\hline
\end{tabular}

n.s. Not significant; ${ }^{* *}$ Significant $(P<0.01)$. 
HEAT PRODUCTION (kJ.kg-0.75. $\mathrm{d}^{-1}$ )

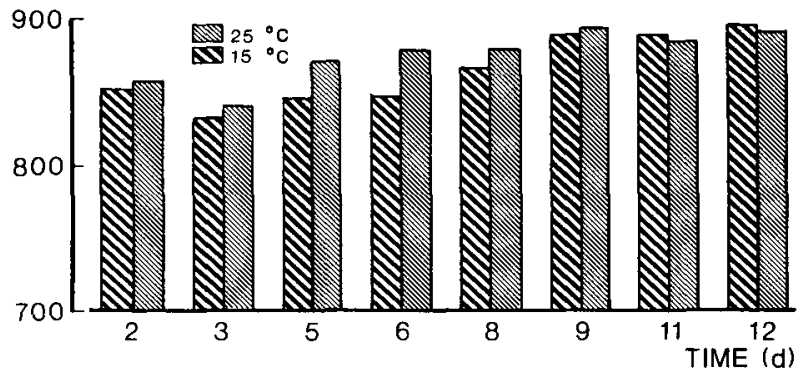

Fig. 3. Heat production $\left(\mathrm{kJ} \cdot \mathrm{kg}^{-0.75} \cdot \mathrm{d}^{-1}\right)$ at each temperature during the trial.

However the effect on activity-related heat production was significant only in the dark $P<0.01$, Table 6). As the pattern of variance differed between treatments, its time course was analysed by Equation 2 . With time, there was a change in activityfree and activity-associated heat production at $15^{\circ} \mathrm{C}$ in the light but only of activityfree production in the dark; at $25^{\circ} \mathrm{C}$, there was a change only for activity-free production in the light and for activity-associated production in the dark (Table 6). Total heat production in the dark did not change significantly with time (Table 6; Fig. 4). Activity-related heat production at $15^{\circ} \mathrm{C}$ remained steady but at $25^{\circ} \mathrm{C}$ declined. Activity-free heat production at $15^{\circ} \mathrm{C}$ increased after the first two days and approached that at $25^{\circ}$ after 9 days.

Table 6. Significance of the effects of time and replicate on heat production $(H)$, activity-associated heat production $\left(H_{\mathrm{A}}\right)$ and activity-free heat production $\left(H_{\mathrm{F}}\right)$ in the light and dark at each temperature treatment $\cdot r^{2}$ = determination coefficient: fraction of variance explained by the statistical model (Model 2).

\begin{tabular}{|c|c|c|c|c|c|}
\hline$H$ & & $H_{\mathrm{A}}$ & & $H_{\mathrm{F}}$ & \\
\hline $25^{\circ} \mathrm{C}$ & $15^{\circ} \mathrm{C}$ & $25^{\circ} \mathrm{C}$ & $15^{\circ} \mathrm{C}$ & $25^{\circ} \mathrm{C}$ & $15^{\circ} \mathrm{C}$ \\
\hline
\end{tabular}

\section{Light}

Replicate

Time

$r^{2}(\%)$

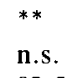

82.5

Dark

Replicate

Time

$r^{2}(\%)$ n.s.

70.8

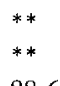

88.6

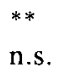

90.3

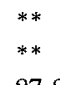

87.8

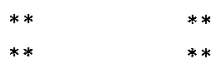

82.5
84.6

n.s. Not significant; ${ }^{*}$ Significant $(P<0.05) ;{ }^{*}$ Significant $(P<0.01)$. 

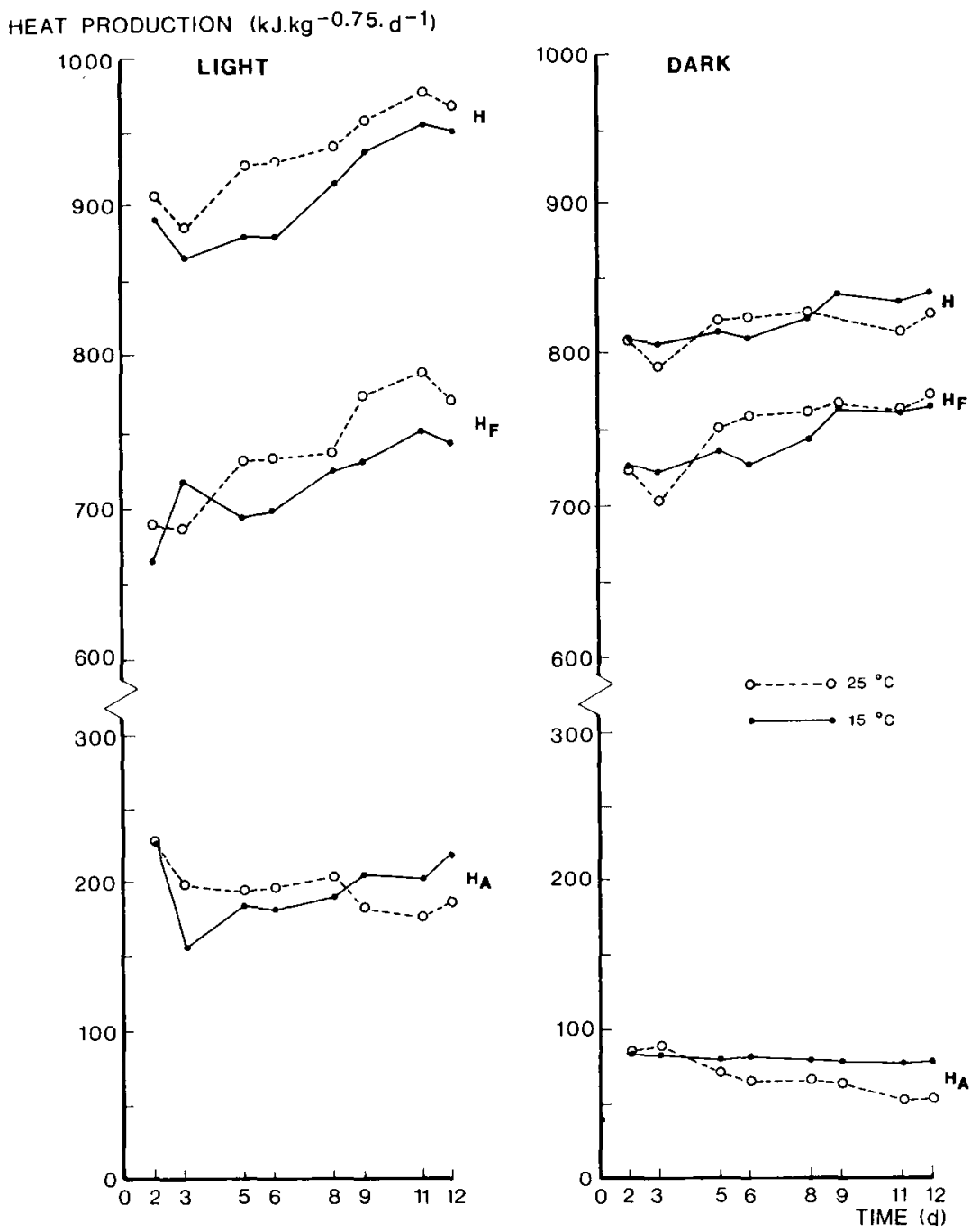

Fig. 4. Least-square mean heat production $(H)$, activity-free heat production $\left(H_{\mathrm{F}}\right)$ and activity-related heat production $\left(H_{\mathrm{A}}\right)$ for each temperature treatment in light and dark $\left(\mathrm{kJ} \cdot \mathrm{kg}^{-0.75} \cdot \mathrm{d}^{-1}\right)$.

\section{Discussion}

Determination of acclimation and its dependence on time is important with diseases related to environmental conditions. Dantzer \& Mormede (1983) and Kelley (1980) showed that climatic factors and their duration influence the magnitude of climatic stress and therefore influence immunological properties and health. It has been shown that metabolic rate and immune function are related. Thus acclimation has an impact on immune function. 
Table 7. Regression coefficients $(b)$ of heat production on time at both temperatures.

\begin{tabular}{|c|c|c|c|c|c|c|c|c|c|c|c|}
\hline \multirow[t]{2}{*}{ Days } & \multicolumn{4}{|c|}{$T=15^{\circ} \mathrm{C}$} & \multicolumn{4}{|c|}{$T=25^{\circ} \mathrm{C}$} & \multicolumn{3}{|c|}{$F$ test } \\
\hline & $n$ & $b_{\mathrm{H}}$ & $b_{\mathrm{A}}$ & $b_{\mathrm{F}}$ & $n$ & $b_{\mathrm{H}}$ & $b_{\mathrm{A}}$ & $b_{\mathrm{F}}$ & $H$ & $H_{\mathrm{A}}$ & $H_{\mathrm{F}}$ \\
\hline \multicolumn{12}{|l|}{ Light } \\
\hline 2 to 12 & 30 & 9.42 & - & 8.07 & 32 & 6.33 & -3.55 & 9.88 & & $*$ & \\
\hline 3 to 12 & 27 & 11.67 & 4.42 & 7.25 & 28 & 7.60 & n.s. & 9.79 & & $* *$ & \\
\hline 5 to 12 & 24 & 12.04 & 3.98 & 8.06 & 24 & 5.29 & n.s. & 7.88 & * & $* *$ & \\
\hline 6 to 12 & 20 & 11.81 & 4.07 & 7.74 & 20 & n.s. & n.s. & 8.41 & * & $* *$ & \\
\hline 8 to 12 & 16 & 7.89 & n.s. & 5.20 & 16 & n.s. & n.s. & n.s. & & $*$ & \\
\hline 9 to 12 & 12 & n.s. & n.s. & n.s. & 12 & n.s. & n.s. & n.s. & & & \\
\hline \multicolumn{12}{|l|}{ Dark } \\
\hline 2 to 12 & 30 & 3.56 & -0.74 & 4.30 & 32 & n.s. & -3.54 & 5.51 & & $*$ & \\
\hline 3 to 12 & 27 & 4.07 & n.s. & 4.81 & 28 & n.s. & -3.60 & 5.74 & & * & \\
\hline 5 to 12 & 24 & 4.23 & n.s. & 4.90 & 24 & n.s. & -2.67 & n.s. & * & & \\
\hline 6 to 12 & 20 & 4.66 & n.s. & 5.67 & 20 & n.s. & -2.73 & n.s. & & & \\
\hline 8 to 12 & 16 & n.s. & n.s. & n.s. & 16 & n.s. & -3.97 & n.s. & & & \\
\hline 9 to 12 & 12 & n.s. & n.s. & n.s. & 12 & n.s. & $\mathrm{n} . \mathrm{s}$ & n.s. & & & \\
\hline
\end{tabular}

n.s. Regression coefficient not significant; ${ }^{* *}$ Significant difference between regression coefficient at 25 and $15{ }^{\circ} \mathrm{C}$ compared to regression coefficient over temperature treatments $(P<0.01) ;^{*} P<0.05$.

Acclimation can be taken to continue until there is no change in heat production or until heat production is independent of temperature. At $15^{\circ} \mathrm{C}$, heat production in the light stopped increasing after 8 days and at $25{ }^{\circ} \mathrm{C}$ after 5 days. At $15^{\circ} \mathrm{C}$ in the dark, it stopped increasing after 6 days. In other words, acclimation took 8 days at $15^{\circ} \mathrm{C}$ and 5 days at $25^{\circ} \mathrm{C}$. The linear effect of time on heat production (expressed by the regression coefficient $b$ ) continued for 8 days in the light and 3 days in the dark, indicating a difference in acclimation (Table 7). The difference is associated with the difference in activity, especially in the dark.

The trials demonstrated the need for all conditions of pigs to be identical apart from the experimental variable, temperature.

\section{Acknowledgements}

The authors thank Mr W. van der Hel, Mr H. A. Brandsma and Mr J. M. van der Linden for assistance with the trials.

\section{References}

Barnett, S. A. \& L. E. Mount, 1967. Resistance to cold in mammals. In: A. H. Nose (Ed.), Thermobiology. Academic Press, London/New York, p. 411-477.

Blecha, F. \& K. W. Kelley, 1981. Effects of cold and weaning stressors on the anti-body mediated immune response of pigs. Journal of Animal Science 53: 439-447.

Brouwer, E. 1965. Report of subcommittee on constants and factors. Proceedings 3th Symposium on Energy Metabolism in Farm Animals, Troon, Scotland. EAAP Publ. 11, p. 441-443.

Bruce, J. M. \& J. J. Clark, 1979. Models of heat production and critical temperature for growing pigs. Animal Production 28: 353-369. 


\section{J. M. F. VERHAGEN, R. GEERS AND M. W. A. VERSTEGEN}

Christison, G. I. \& C. M. Williams, 1982. Effects of cold on animal production. In: CRC Handbook of Agricultural Productivity, Vol. II, p. 69-76.

Close, W. H., 1971. The influence of environmental temperature and plane of nutrition on heat losses from individual pigs. Animal Production 3: 295-302.

Close, W. H., 1981. The climatic requirements of the pig. In: J. A. Clark (Ed.), Environmental aspects of housing for animal production. Butterworths, London, p. 149-166.

Close, W. H., R. P. Heavens \& D. Brown, 1981. The effects of ambient temperature and air movement on heat loss from the pig. Animal Production 32: 75-84.

Dantzer, R. 1973. Etude de la stabilisation des rythmes d'activité locomotrice de porcelets introduit dans un nouvel environment. Journal de Physiologie 66: 495-503.

Dantzer, R. \& P. Mormede, 1983. Stress in farm animals: a need for reevaluation. Journal of Animal Science 57: 6-18.

Fuller, M. T. \& A. W. Boyne. 1972. The effects of environmental temperature on the growth and metabolism of pigs given different amount of feeds. 2. Energy metabolism. British Journal of Nutrition 28: 373-384.

Hacker, R. R., M. P. Stefanovics \& T. R. Batra, 1973. Effects of cold exposure on growing pigs: growth, body composition and 17-keto-steroidsg. Journal of Animal Science 37: 739-744.

Holmes, C. W. \& L. E. Mount, 1967. Heat loss from groups of growing pigs under various conditions of environmental temperature and air movement. Animal Production 9: 435-452.

Kelley, K. W., 1980. Stress and immune function: a bibliographic review. Annuale Recherche Veterinaire 11: 445-478.

Leung, P. B. M. \& B. R. Horowitz, 1976. Free-feeding patterns of rats in response to changes in environmental temperature. American Journal of Physiology 231: 1220-1224.

Morrison, S. R. \& L. E. Mount, 1971. Adaptation of growing pigs to changes in environmental temperatures. Animal Production 13: 51-57.

Mount, L. E., 1979. Adaptation to thermal environment: man and his productive animals. Edward Arnold, London.

Mount, L. E., I. B. Start \& D. Brown, 1980. A note on the effects of forced air movement and environmental temperature on weight gain in the pig after weaning. Animal Production 30: 295-298.

SAS, 1985. Statistical Analysis System. SAS Institute Inc., Cary NC.

Siegel, H. S., 1980. Physiological stress in birds. Bioscience: $529-534$.

Snedecor, G. W. \& C. Cochran, 1967. Statistical Methods. Iowa State University Press.

Thorbek, G., A. Chwalibog \& S. Henckel, 1982. Energy requirements for maintenance and growth in pigs from 20-100 kg live weight. Proceedings 9th Symposium on Energy Metabolism of Farm Animals, Lillehammer, Norway.

Van der Hel, W., M. W. A. Verstegen, W. Baltussen \& H. Brandsma, 1984. The effect of ambient temperature on diurnal rhythm in heat production and activity in pigs kept in groups. International Journal of Biometeorology 28: 303-315.

Van der Hel, W., R. Duijghuisen \& M. W. A. Verstegen, 1986. The effect of ambient temperature and activity on the daily variation in heat production of growing pigs kept in groups. Netherlands Journal of Agricultural Science 34: 173-184.

Verhagen, J. M. F., A. A. M. Kloosterman, A. Slijkhuis \& M. W. A. Verstegen, 1987. Effect of duration of ambient temperature exposure on energy metabolism in growing pigs. Animal Production 44: 427-433.

Verstegen, M. W. A., W. van der Hel, H. A. Brandsma \& E. Kanis, 1982. Heat production of groups of growing pigs as affected by weight and feeding level. Proceedings 9th Symposium on Energy Metabolism of Farm Animals, Lillehammer, Norway.

Verstegen, M. W. A., W. van der Hel, H. A. Brandsma, A. M. Henken \& A. M. Bransen, 1987. The Wageningen respiration unit for animal production research: a description of the equipment and its possibilities. In: M. W. A. Verstegen \& A. M. Henken (Eds), Energy metabolism in farm animals: effects of housing, stress and disease. Martinus Nijhof, Dordrecht, pp. 21-48.

Wenk, C. \& A. J. H, van Es, 1980. Untersuchungen über den Stoff- und Energiewechsel wachsender Küken unter besonderer Berücksichtigung der Aktivität. Zeitschrift für Tierphysiologie, Tierernährung und Futtermiddelkunde 43: 241-154. 